Marta Kosicka*

\title{
Zaburzenia mowy postaci z bajek i ich wpływ na rozwój mowy dzieci
}

Speech disorders of fairy-tale characters And Their Impact On The Development Of Children's Speech

Słowa kluczowe: językoznawstwo, logopedia, zaburzenia mowy, postacie z bajek, oddziaływanie mediów, rozwój języka Keywords: linguistics, logopaedics, speech disorders, characters from fairy-tale characters, language development

\section{Wprowadzenie}

Powszechnie wiadomo, że zbyt długie spędzanie przez dzieci wolnego czasu przed szklanym ekranem niesie mniej lub bardziej niepokojące skutki. Dziecięce umysły, które chłoną wszelkie informacje z zewnątrz, często nie potrafią oddzielić fikcji od rzeczywistości, co może powodować utrwalanie się nieprawidłowych wzorców zachowania lub komunikacji [Kołodziejczyk, 2003, s. 42; Korzeniowska, 2016, s. 76]. Media XXI wieku silnie oddziałują na sferę biologiczno-fizyczną, poznawczą, emocjonalną, ale też na samo zachowanie najmłodszych [Izdebska, 2001, s. 35; Sak, 2016, s. 185]. Telewizor, który jest często kolejnym członkiem rodzinnej społeczności, swoją „aktywną” obecnością zaburza nie tylko kontakty dziecka z innymi, ale przede wszystkim może stanowić ryzyko dla jego prawidłowego rozwoju, w tym rozwoju mowy [Izdebska, 2001, s. 212, 221].

Głównym celem artykułu jest charakterystyka języka postaci z bajek i programów telewizyjnych oraz przedstawienie wyników własnych badań na temat wpływu jakości ich mowy na rozwój mowy dzieci w wieku przedszkolnym.

\footnotetext{
* Przedszkole Miejskie nr 215, ul. Budowlana 11/13, 93-356 Łódź, e-mail: mjk10@wp.pl.
} 


\section{Język postaci z bajek}

Na podstawie typologii odmian językowych, którą proponuje Aleksander Wilkoń [2000, s. 106], język postaci z bajek można uznać za „połączenie języka pisanego artystycznego i języka mówionego potocznego" [Samborska, 1999, s. 728]. Pierwszy z nich cechuje się tendencją zachowawczo-nowatorską, która z jednej strony polega na respektowaniu norm ogólnego języka pisanego, z drugiej zaś może negować niektóre normy języka artystycznego. Język mówiony „charakteryzuje się naturalną, swobodną wymową, bez zbyt rygorystycznego przestrzegania prawideł poprawnościowych" [Samborska, 2004, s. 75]. Warto również podkreślić, że tekst bajki, który zostaje wygłoszony, powstaje w sytuacji sztucznej i skonwencjonalizowanej [Samborska, 2004, s. 75]. Specyfikę języka postaci z bajek przedstawiono na rysunku 1.

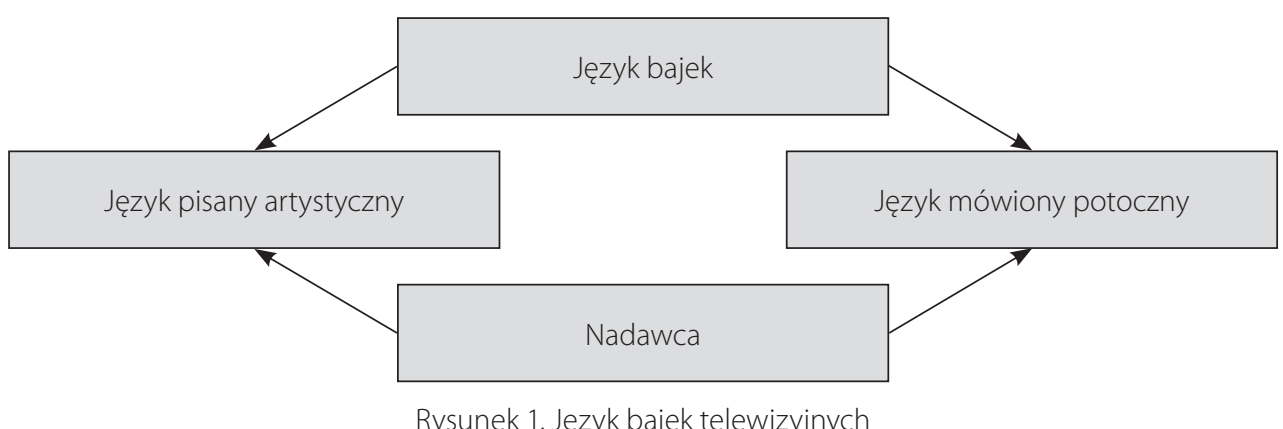

Źródło: opracowanie własne na podstawie Samborska, 1999, s. 727-731.

Wydawać by się mogło, że język postaci z bajek, czyli wcześniej opracowany tekst, powinien być wygłoszony poprawnie, nie odbiegać od ogólnopolskiej normy i stanowić wzór dla najmłodszych widzów [Samborska, 1999]. Jednak wnioski z badań Iwony Samborskiej, która analizowała teksty bajek, oraz Anny Łobos i Małgorzaty Kity, które zajęły się opisaniem języka poszczególnych programów telewizyjnych dla dzieci, wskazują, że do najistotniejszych cech języka bajek można zaliczyć:

1) naturalną i swobodną wymowę [Samborska, 1999, s. 730];

2) nierygorystyczne podejście do prawideł poprawnościowych [Samborska, 1999, s. 730];

3) przewagę zdań pojedynczych i krótkich nad zdaniami wielokrotnie złożonymi [Łobos, 2003, s. 124-125];

4) częste występowanie kolokwializmów, anglicyzmów oraz wyrazów potocznych [Łobos, 2003, s. 129-130];

5) bardzo szybkie i wypowiadane podniesionym głosem kwestie bohaterów (często mówione wrzaskliwie, piskliwie) [Samborska, 1999, s. 730]; 
6) wadliwą wymowę osób dubbingujących, którzy, naśladując dziecięce zachowania językowe, używają tak zwanej mowy-do-dzieci' ${ }^{1}$ [Kita, 1993, s. 106].

To właśnie ostatnia cecha języka bajek zainspirowała autorkę do zbadania piętnastu postaci z bajek (załącznik 1), które, dzięki aktorom dubbingującym, sprawnie naśladującym wady wymowy, zostały scharakteryzowane między innymi przy użyciu różnych zaburzeń mowy, takich jak dyslalia, nosowanie czy jąkanie².

\section{Badania własne}

W badaniach prowadzonych na terenie jednego z miejskich przedszkoli w Pabianicach wzięło udział 128 osób - 64 rodziców oraz 64 dzieci w wieku od 4 do 6 lat. Grupa A liczyła 32 rodziców (A1) oraz ich dzieci (A2), które w trakcie badania nie miały zdiagnozowanej wady wymowy. Grupę B reprezentowało natomiast 32 rodziców (B1) oraz ich dzieci (B2), które zostały zdiagnozowane przez logopedę i w większości uczęszczały na terapię logopedyczną. W zbieraniu informacji wykorzystano badanie ankietowe za pomocą autorskiego kwestionariusza skierowanego do rodziców (załącznik 2) oraz wywiadów (załącznik 3), które autorka przeprowadziła z dziećmi.

\section{Wyniki badań własnych - ankiety dla rodziców}

Celem pierwszego pytania skierowanego do rodziców było przede wszystkim wyłonienie bohaterów bajek, których dzieci oglądają najchętniej. Wśród najczęstszych odpowiedzi pojawili się: Zygzak Mcqueen, Spiderman, Chase, Dora, Elsa, Myszka Miki. Rodzice dzieci z wadami wymowy podawali więcej postaci występujących w różnych bajkach ( $\mathrm{B} 1=27$ różnych bohaterów) niż rodzice dzieci bez wad wymowy $(\mathrm{A} 1=21$ różnych bohaterów).

Na pytanie „Czy dana postać ma wadę wymowy/mówi niewyraźnie?” rodzice obu grup zwykle odpowiadali przecząco. Procent odpowiedzi przeczących w obu grupach łącznie stanowił $86 \%$ wszystkich odpowiedzi. W przypadku zaznaczenia odpowiedzi „tak”, w celu sprawdzenia, co rodzicie traktowali za niewyraźną mowę, proszeni byli o pisemne rozwinięcie swojej opinii. Większość rodziców nie umiała jednak zidentyfikować błędów mowy/wymowy wskazanej postaci bądź niesłusznie klasyfikowała

1 M. Kita pisze, że mowę-do-dzieci rozumiemy jako „głos skrzeczący, bardzo cienki, mówienie przez nos, jąkanie się, przedłużanie artykulacji głosek, wielość elementów paralingwistycznych. [...] Dołącza się do tych zjawisk niekiedy dodatkowa artykulacja głosek, głównie labializacja, dentalizacja i lekka palatalizacja" [1993, s. 106].

2 Serdeczne podziękowania składam dr Ewelinie Zając za wiarę i pomoc w realizacji autorskich badań oraz dr Monice Kaźmierczak za okazane wsparcie, cenne wskazówki i nieustającą motywację w trakcie pisania artykułu. 
ich mowę jako nieprawidłową. Zaledwie kilku wskazało poprawnie na odstępstwo od normy, podając przykład: „Minionki - inny język” oraz „Tygrysek - sepleni”.

Naśladowanie mowy postaci z bajek przez dzieci potwierdza łącznie $50 \%$ ankietowanych rodziców obu badanych grup. Dorośli, którzy odpowiedzieli twierdząco na to pytanie, proszeni byli o pisemne doprecyzowanie swoich obserwacji. Zróżnicowane odpowiedzi dotyczyły głównie zmian w zachowaniu i mowie dziecka. W obu grupach pojawiły się odpowiedzi typu: „Powtarza dialogi, piosenki”, „Zachowuje się jak postać z bajki”, „Zmienia intonacje”, „Naśladuje odgłosy aut, strzałów”, „Mówi bardzo wyraźnie, akcentując każde słowo”, „Mówi po angielsku”.

Na pytanie „Czy zauważyli Państwo nagłe pogorszenie wymowy dziecka po obejrzeniu jakiejś bajki/filmu/kreskówki?” 95,3\% rodziców obu grup odpowiedziało przecząco. Pozostały procent dorosłych miał za zadanie pisemnie wyjaśnić, jaką zmianę dostrzeżono. W grupie A1 pojawiły się odpowiedzi: „Pogorszenie słownictwa na wulgarne”, „Wraca do tzw. dzidziusia - spieszcza mowę”, natomiast w grupie B1: „Wymowa polepszyła się”, „Łapie słownictwo, grzeczna wymowa”. Najbardziej niepokojąca ze wszystkich odpowiedzi brzmiała: „Po obejrzeniu bajki Max i Rubby zaczęła komunikować się poprzez jeden wyraz, tak jak postać z bajki”.

Badania dowodzą, że rodzice kojarzą imiona bądź wygląd bohaterów bajek dla przedszkolaków. Około 97\% rodziców zaznaczyło imię co najmniej jednego bohatera, co potwierdza oglądanie przez ich dzieci bajek z bohaterami z zaburzeniami mowy/wadami wymowy.

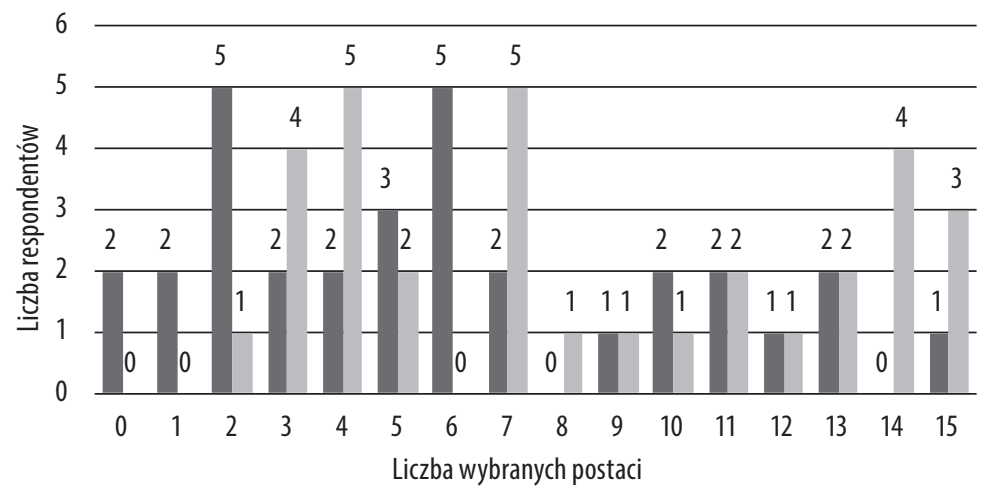

a Rodzice dzieci bez wad wymowy $\quad$ Rodzice dzieci z wadami wymowy

Rysunek 2. Liczba oglądanych przez dzieci postaci z zaburzeniami mowy - w opinii rodziców; z podziałem na grupy

Źródło: opracowanie własne.

W badaniu liczby oglądanych postaci z zaburzeniami mowy najniższą odnotowaną liczbą wybranych bohaterów bajek przez rodziców było 0 , a największą 15 . Średnio każdy z rodziców w grupie A1 wskazał 6 postaci $(5,88)$ z filmów animowanych, 
a w grupie B1 ponad 8 postaci $(8,34)$. Co za tym idzie, według deklaracji rodziców dzieci z wadami wymowy oglądają o $42 \%$ więcej wymienionych w ankiecie postaci z zaburzeniami mowy niż dzieci bez wad wymowy. Z wypowiedzi rodziców i wyników badań własnych można wnioskować, że wadliwa wymowa postaci z bajek może mieć wpływ na rozwój mowy dziecka, a w niektórych przypadkach nawet przyczyniać się do powstawania bądź utrwalania wad wymowy.

Poza ogólną orientacją rodziców dotyczącą postaci z zaburzeniami mowy w bajkach, badania wykazały, która animowana postać z piętnastu wskazanych w kwestionariuszu ankiety jest najczęściej oglądana przez dzieci. Najchętniej oglądanych bohaterów przedstawia rysunek 3 .

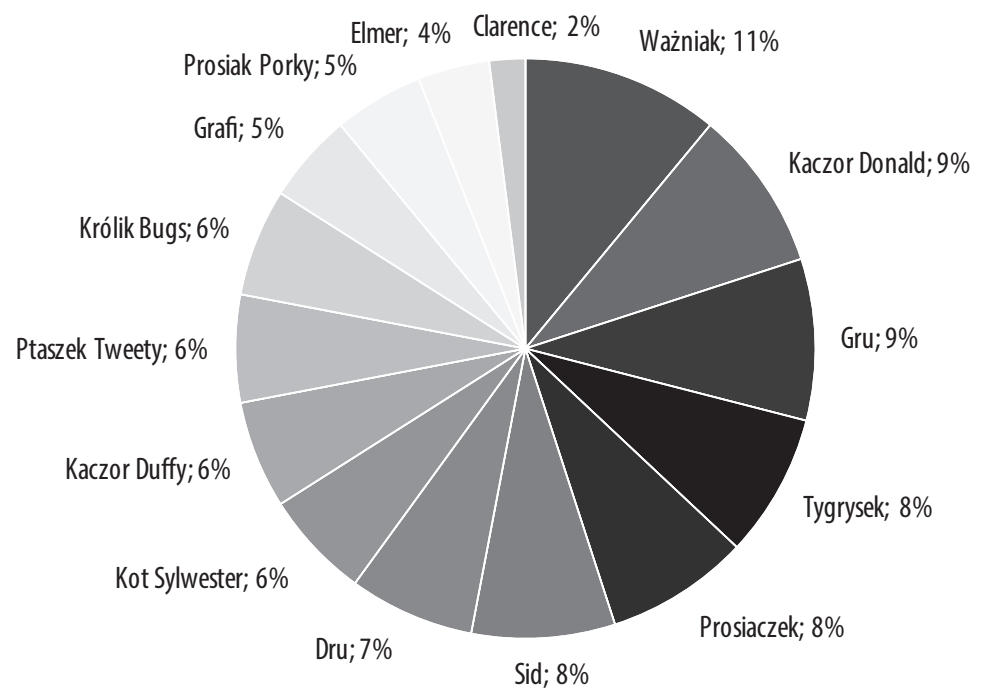

Rysunek 3. Najchętniej oglądane przez dzieci postaci z bajek - w opinii rodziców

Źródło: opracowanie własne.

$\mathrm{Z}$ analizy danych wynika, że najczęściej wybieraną postacią przez badane dzieci jest Ważniak z bajki Smerfy (około 11\% wszystkich odpowiedzi), a najrzadziej postać z kreskówki Clarence (około 2\% odpowiedzi). Dużą popularnością wśród przedszkolaków cieszą się również Kaczor Donald i Gru z filmu Minionki (po około 9\% odpowiedzi), przyjaciele Kubusia Puchatka: Tygrysek i Prosiaczek oraz Sid z Epoki lodowcowej (po około 8\%). Ponad 90\% rodziców obu badanych grup deklaruje, że dostrzega nienormatywną mowę/wymowę chociaż u jednej postaci, które wymieniono $\mathrm{w}$ ankiecie. Rysunek 4 przedstawia liczbę bohaterów z zaburzeniem mowy (z podanych w ankiecie) rozpoznanych przez dorosłych.

Zadanie rozpoznania postaci z zaburzeniami mowy okazało się dość trudne dla respondentów. Zaledwie jeden dorosły z grupy B1 prawidłowo stwierdził, iż mowa każdego z zaproponowanych w ankiecie bohaterów bajek, filmów i kreskówek odbiega od normy. 
Każdy z rodziców z grupy A1 średnio zaznaczył około 4 postaci $(3,81)$, a z grupy B1 ponad 4 postaci $(4,59)$. Co istotne, wśród bohaterów oglądanych przez dzieci rodzice z grup A1 i B1 dostrzegli nieprawidłowości odpowiednio u około 34\% i 33\% postaci z bajek. W konsekwencji każda osoba z grupy A1 zaznaczyła średnio 2 postaci, a w grupie B2 około 3 postaci. Bohaterem, u którego zaburzenie mowy trafnie wskazała największa liczba rodziców obu grup i który jednocześnie był oglądany przez ich dzieci, był Kaczor Donald (20\%), natomiast najmniej wskazało Clarence’a (około 1\%). Zdarzało się, że rodzic, który wcześniej nie zaznaczył postaci oglądanej przez swoje dziecko, podkreślał tę, którą uważał za mówiącą niepoprawnie. W grupie A1 wśród postaci nieoglądanych przez dzieci rodzice wskazali około $20 \% \mathrm{z}$ zaburzeniem mowy lub wadą wymowy, a w grupie B1 około 27\%. Dorośli wskazywali najczęściej Grafiego (około 17\% odpowiedzi), natomiast żaden z dorosłych nie wskazał ani Gru, ani Dru z filmu Minionki.

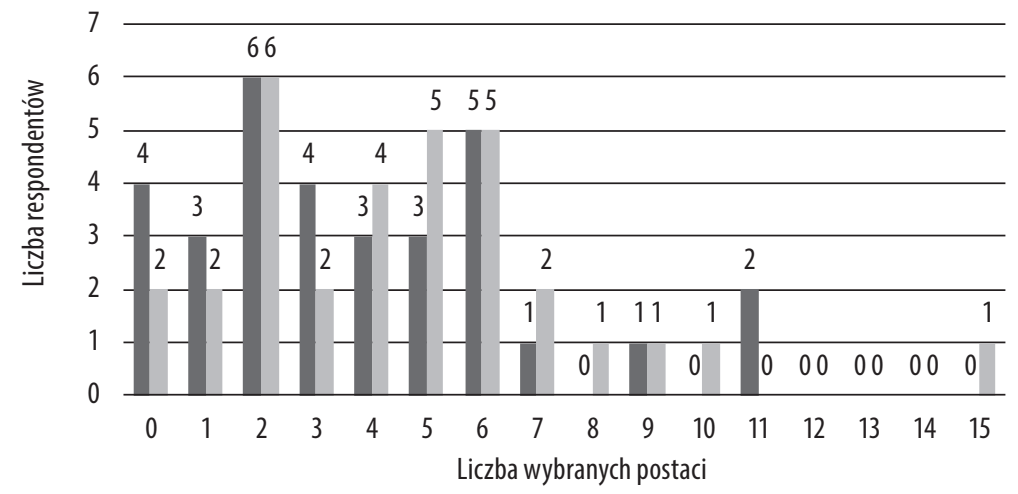

\footnotetext{
- Rodzice dzieci bez wad wymowy $\quad$ Rodzice dzieci z wadami wymowy

Rysunek 4. Liczba rozpoznanych przez rodziców postaci z zaburzeniami mowy (z podanych w ankiecie), z podziałem na grupy

Źródło: opracowanie własne.
}

Kolejna grupa pytań zawartych w ankiecie dla rodziców służyła określeniu średniej ilości czasu przeznaczanego przez dziecko na oglądanie bajek z postaciami mającymi zaburzenia mowy lub wady wymowy. Wyniki dotyczące czasu oglądania bajek przedstawia rysunek 5 .

Z rysunku 5 wynika, iż średni czas przeznaczany na oglądanie bajek z postaciami mającymi zaburzenia mowy to 1 godzina 7 minut w grupie A2 i 1 godzina 27 minut w grupie B2. Tak więc dzieci z wadami wymowy poświęcają w ciągu dnia średnio 20 minut więcej na oglądanie postaci, które wskazano w ankiecie, niż dzieci, które nie mają wad wymowy. W skali tygodnia daje to średnio różnicę ponad 2 godzin, w miesiącu 10 godzin, natomiast w roku ponad 121 godzin.

Dodatkowo dorosłych respondentów zapytano o czas poświęcany na rozmowę z dziećmi na temat oglądanych bajek. Obie grupy rodziców odpowiadały różnie 
na to pytanie. Spośród 5 możliwych wariantów najczęściej wybierana była odpowiedź: „,codziennie”, jednak to rodzice z grupy A1 poświęcają o 16,6\% więcej czasu na rozmowę ze swoim dzieckiem niż rodzice z grupy B1.

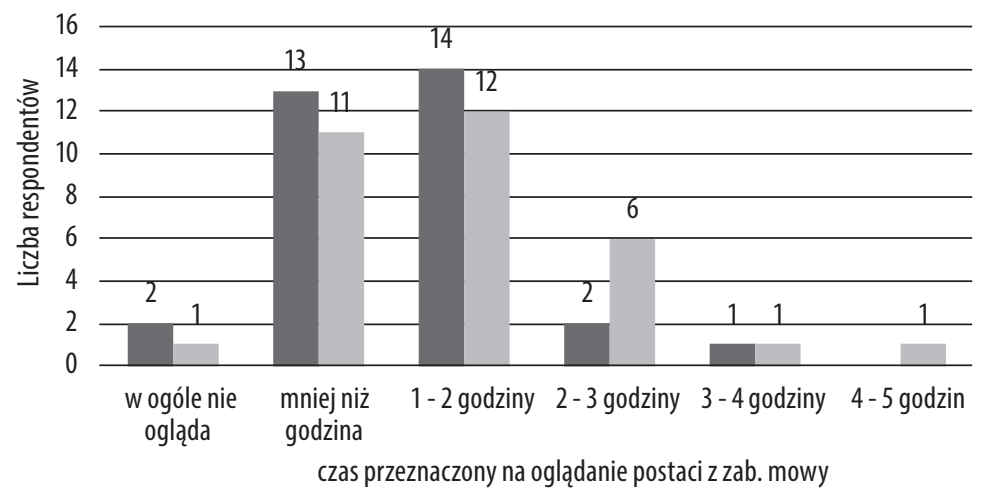

• Rodzice dzieci, które nie mają wad wymowy $\quad$ Rodzice dzieci, które mają wady wymowy

Rysunek 5. Ilość czasu przeznaczonego na oglądanie przez dzieci postaci z zaburzeniami mowy - w opinii rodziców

Źródło: opracowanie własne.

Ostatnie dwa pytania skierowane do rodziców dotyczyły ich opinii na temat postaci $\mathrm{z}$ wadami wymowy. Pierwsze $\mathrm{z}$ nich wiązało się $\mathrm{z}$ wpływem wymowy postaci z bajek na artykulację dziecka - w sumie $81 \%$ rodziców stwierdziło, że wadliwa wymowa bohaterów może oddziaływać na dziecko. Drugie pytanie miało natomiast za zadanie zweryfikować, czy rodzice uważają, że postacie z zaburzeniami mowy mogą bądź powinny występować w bajkach. Spośród 5 wariantów w sumie w obu grupach odpowiedź „zdecydowanie tak” zaznaczyło 1,6\% rodziców, „tak” $28,1 \%$, „trudno powiedzieć” $14,1 \%$, „nie” $25 \%$, a „zdecydowanie nie” $31,2 \%$ respondentów.

\section{Wyniki badań własnych - wywiady z dziećmi}

Z wywiadów, które przeprowadzono z dziećmi zarówno w grupie A2, jak i B2 wynika, że wszystkie oglądały bądź oglądają bajki, których bohaterowie zostali wymienieni w kwestionariuszu. Liczbę wskazanych postaci przez dzieci, z podziałem na grupy, przedstawia rysunek 6 .

Odpowiedzi dzieci i rodziców z grup A dotyczące średniej liczby oglądanych postaci nieznacznie różnią się od siebie, natomiast w przypadku grup B dzieci wskazały mniejszą liczbę postaci niż ich rodzice. Na podstawie przeprowadzonych wywiadów można stwierdzić, że dzieci z obu grup znają średnio po 6 ze wskazanych 
postaci (odpowiednio A2 =6,09, B2 =6,53). Wykaz najchętniej oglądanych bohaterów bajek spośród podanych w spisie przedstawia rysunek 7 .

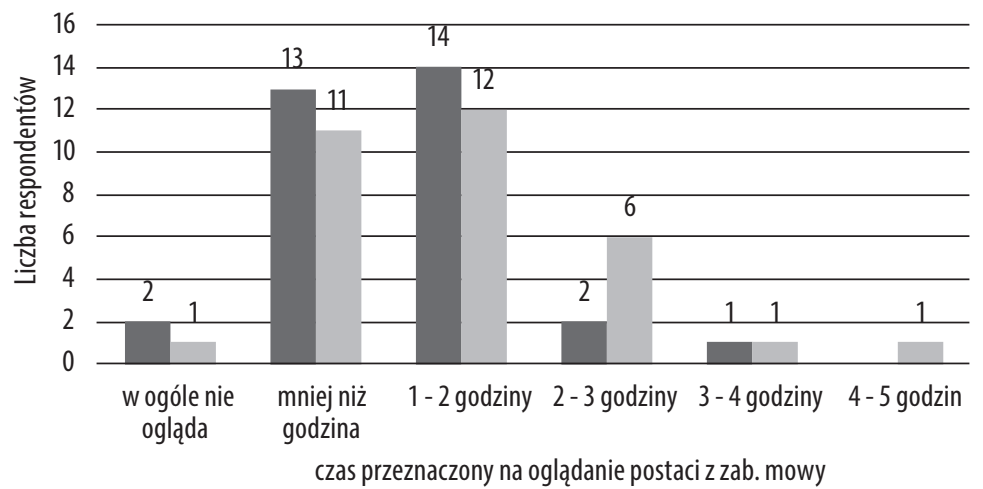

• Rodzice dzieci, które nie mają wad wymowy $\quad$ Rodzice dzieci, które mają wady wymowy

Rysunek 6. Liczba postaci z zaburzeniami mowy oglądanych przez dzieci, z podziałem na grupy

Źródło: opracowanie własne.

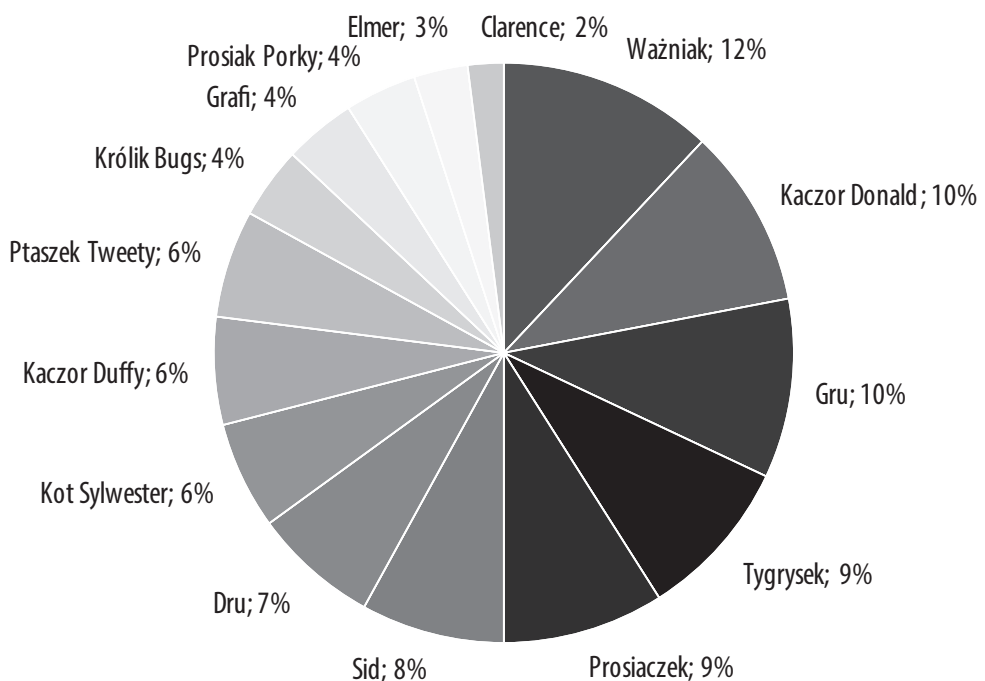

Rysunek 7. Postacie z bajek najchętniej oglądane przez dzieci

Źródło: opracowanie własne.

Tak jak w przypadku ankiet dla rodziców, analiza ustnych odpowiedzi dzieci pozwala wnioskować, że bajkom ze wskazanymi w ankiecie bohaterami przedszkolaki poświęcają najwięcej uwagi. Najczęściej oglądaną postacią w obu grupach małych respondentów jest Ważniak (około 12\% wszystkich odpowiedzi), natomiast najrzadziej Prosiak Porky (około 2\% wszystkich odpowiedzi). Porównując postacie najczęściej 
typowane przez dzieci i rodziców, można zauważyć, że w pierwszej trójce znaleźli się ci sami bohaterowie. Prowadzi to do wniosku, że zainteresowanie rodziców bajkami, jakie oglądają ich dzieci, jest duże.

$\mathrm{W}$ trakcie rozmowy z dziećmi próbowano się dowiedzieć, czy postacie z zaburzeniami mowy im się podobają, a ich wadliwa mowa budzi sympatię. W sumie $98,4 \%$ dzieci stwierdziło, że lubi postacie z zaburzeniami mowy, a około 92,2\% uznało, że mowa postaci ze wskazanych bajek jest atrakcyjna.

Następnie badane dzieci zostały poproszone, aby wyjaśniły, dlaczego mowa postaci z bajek im się podoba bądź nie. Za interesujące uznały przede wszystkim dialogi postaci oraz to, że ich mowa jest „fajna”, „zabawna” i „różni się od ludzkiej”. Dzieci, którym mowa postaci z bajek nie podobała się, za główny powód podawały jej „niedokładność”.

Co więcej, prawie połowa dzieci stwierdziła, że lubi naśladować mowę postaci z bajek, jednak większość przedszkolaków - około $86 \%$ wszystkich badanych - uznała, że nie potrafi mówić tak jak wymienione postacie z zaburzeniami mowy.

Bardzo istotna była opinia dzieci na temat tego, czy utożsamiają swoją mowę z mową postaci z bajek. Około 79,7\% wszystkich badanych przedszkolaków nie widzi podobieństwa między swoją mową a tą występującą u bohaterów z zaburzeniami mowy. Jednak procentowy odsetek odpowiedzi „nie” w grupie A2 jest mniejszy (75\%) niż w grupie B2 (84,4\%).

\section{Podsumowanie i wnioski}

Na podstawie prezentowanych badań można stwierdzić, że telewizję, a dokładniej bajki animowane i obecnych w nich bohaterów z zaburzeniami mowy, można traktować jako czynnik różnicujący zachowania werbalne u dzieci biorących udział w badaniu. Odpowiedzi dzieci były niemal tożsame z tymi, których udzielili rodzice, co wskazuje na stosunkowo duże zainteresowanie rodziców tekstami kultury, które mają wpływ na rozwój ich dzieci. Najbardziej niepokoi, że dzieci z wadami wymowy przeznaczają na oglądanie bajek z postaciami, u których występują zaburzenia mowy, więcej czasu niż dzieci w normie. Może to prowadzić do naśladowania nieprawidłowego wzorca (na co wskazywali rodzice) czy wystąpienia dodatkowych trudności w prowadzonej terapii logopedycznej. Wynika to z faktu, że większość dzieci przedszkolnych nie jest świadoma własnych zaburzeń mowy, nie potrafi też rozpoznać ich u ulubionych bohaterów. Naśladowanie wadliwej mowy, często niewłaściwego zachowania, a także rzadsze rozmowy rodziców z dziećmi o postaciach z bajek i pozwalanie na ich dłuższe oglądanie może w konsekwencji prowadzić do utrwalania się nieprawidłowości u małych odbiorców.

Przeprowadzone badania miały na celu przede wszystkim uwrażliwić rodziców oraz opiekunów na mowę postaci z bajek oraz uświadomić im, w jaki sposób mowa 
i wymowa bohaterów może manifestować się w mowie dzieci przedszkolnych. Już na etapie badań można było zaobserwować, że przy kolejnych pytaniach ankiety rodzice nieco krytyczniej oceniali nienormatywną mowę bohaterów bajek, choć trudno im było od razu określić jednoznacznie jej wpływ na rozwój mowy dzieci.

\section{Załącznik 1}

Zaproponowane w ankiecie oraz wywiadzie postacie z zaburzeniami mowy, występujące w bajkach, filmach bądź kreskówkach

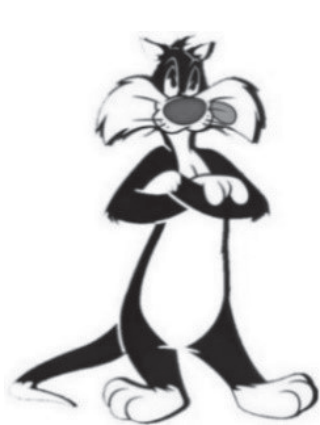

Kot Sylwester

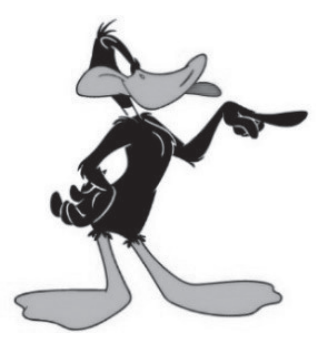

Kaczor Duffy

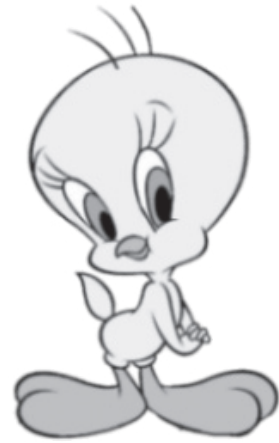

Ptaszek Tweety

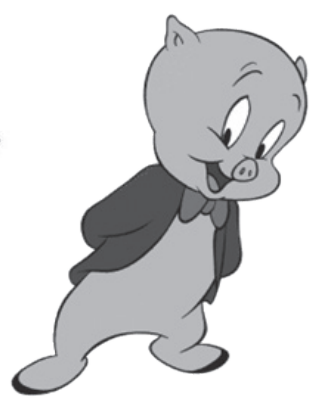

Prosiak Porky

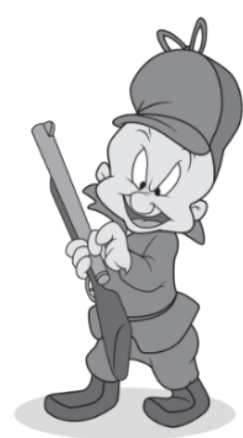

Elmer Fudd

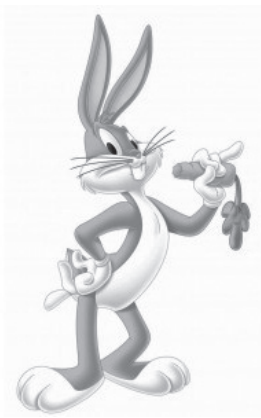

Królik Bugs

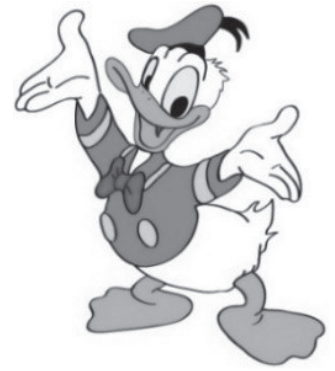

Kaczor Donald

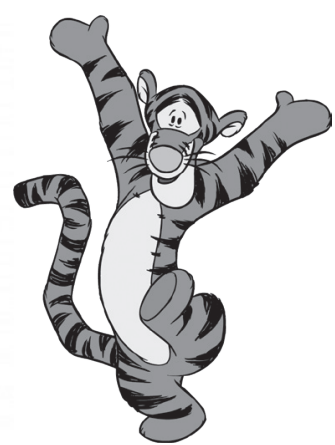

Tygrysek 


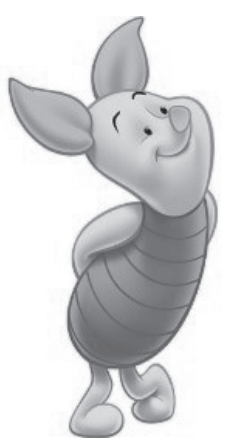

Prosiaczek

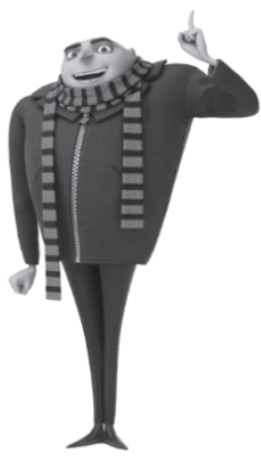

Gru

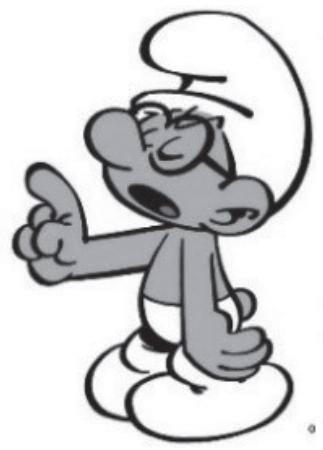

Ważniak

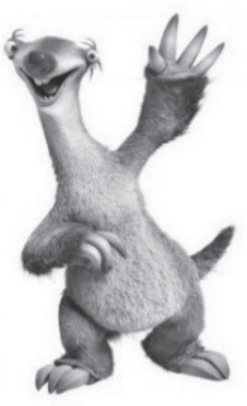

Sid

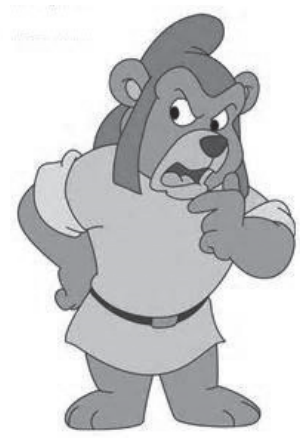

Grafi

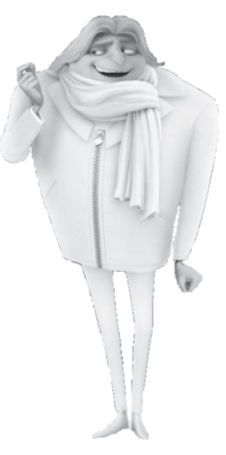

Dru

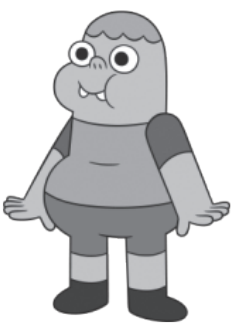

Clarence

Źródła: Kot Sylwester, http://slimtex.pl/ZABAWKI2011/13389\%20Looney\%20Tunes\%20-\%20Kot\%20Sylwester\%20 28\%20cm/2.jpg (dostęp: 10.11.2018); Ptaszek Tweety, http://clipart-library.com/clipart/1985691.htm (dostęp: 10.11.2018); Elmer Fudd, https://www.wbkidsgo.com/portals/4/Images/Content/Characters/Elmer\%20Fudd/fuddbody.png?ver=2015-12-03-184959-820 (dostęp: 10.11.2018); Kaczor Donald, https://allegro.pl/naklejki-do-pokojukaczor-donald-disney-rozmiar-xl-i7246114757.html (dostęp: 10.11.2018); Kaczor Duffy, https://st-listas.20minutos.

es/images/2017-08/423725/5209145_640px.jpg?1504185350 (dostęp: 10.11.2018); Prosiak Porky, http:// pl.zwariowanemelodie.wikia.com/wiki/Prosiak_Porky?file=Porky-pig-porky-pig-21732064-236-300.gif (dostęp: 10.11.2018); Królik Bugs, http://www.krolik-bugs.com/galeria/data/media/1/ZoomlmageFramer.aspx.jpg (dostęp: 10.11.2018); Tygrysek, https://i1.wp.com/worldartsme.com/images/disney-tigger-clipart-1.jpg (dostęp: 10.11.2018); Prosiaczek, https://vignette.wikia.nocookie.net/disney/images/b/bb/Free_walt_disney_piglet_wallpaper.jpg/ revision/latest?cb=20140415074205 (dostęp: 10.11.2018); Ważniak, http://lustrzananadzieja.blogspot.com/2015/05/ smerf-tag.html (dostęp: 10.11.2018); Sid, https://wallpapercave.com/wp/3Jp8x93.jpg (dostęp: 10.11.2018); Grafi, https://www.pinterest.com.mx/pin/325385141807506277/ (dostęp: 10.11.2018); Gru, http://princebalto.wikia.com/ wiki/Gru?file=Gru.jpg (dostęp: 10.11.2018); Dru, https://vignette2.wikia.nocookie.net/despicableme/images/5/5e/ Dru.png/revision/latest/scale-to-width-down/250?cb=20170301062036 (dostęp: 10.11.2018); Clarence, http:// www.boing.es/sites/boinges/files/styles/character_list_page/public/PERSONAJES_WEB_CLARENCE_CLARENCE_ BOING.png?itok=Vm8_zBrC (dostęp: 10.11.2018). 


\section{Załącznik 2}

\section{Kwestionariusz ankiety dla rodziców}

1. Którą postać z bajki/kreskówki/filmu Państwa dziecko lubi najbardziej? (nie musi być to postać zaproponowana przeze mnie)

2. Czy dana postać ma wadę wymowy/mówi niewyraźnie?

Tak Nie

Jeśli tak, to co zwróciło Państwa uwagę?

3. Czy Państwa dziecko naśladuje wymowę jakiejś postaci z bajki/kresków$\mathrm{ki} / \mathrm{filmu}$ ?

Tak Nie

Jeśli tak, to co dokładnie robi bądź przestało robić?

4. Czy zauważyli Państwo nagłe pogorszenie wymowy u dziecka po obejrzeniu jakiejś bajki/kreskówki/filmu?

Tak Nie

Jeśli tak, to jakie?

5. Czy Państwa dziecko ogląda bądź oglądało bajkę, w której występują zaproponowane przeze mnie postacie?

Tak Nie

Jeśli tak, to proszę postawić przy danej postaci krzyżyk „X”.

6. Czy któraś z zaproponowanych przeze mnie postaci ma wadę wymowy/mówi nieprawidłowo?

Tak Nie

Jeśli tak, to proszę podkreślić daną postać.

7. Ile czasu w ciągu dnia Państwa dziecko poświęca na oglądanie bajek/filmów/ kreskówek z postaciami zaproponowanymi wcześniej przeze mnie?
a) mniej niż godzinę
b) 1-2 godziny
c) 2-3 godziny
d) 3-4 godziny
e) 4-5 godzin
f) w ogóle nie ogląda

8. Jak często rozmawiają Państwo ze swoim dzieckiem o postaciach oglądanych w bajkach/filmach/kreskówkach?

codziennie często czasami rzadko nigdy


9. Czy uważają Państwo, że wymowa u postaci z bajek może mieć wpływ na mowę dziecka?

Tak Nie

10. Czy uważają Państwo, że w bajkach mogą/powinny występować postacie z wadami wymowy?

zdecydowanie tak tak trudno powiedzie nie zdecydowanie nie

\section{Załącznik 3}

\section{Kwestionariusz wywiadu dla dzieci}

\section{Czy rozpoznajesz którąś z tych postaci?}

Tak Nie

Jeśli tak, to jaką? Pokaż palcem, powiedz jej imię.

\section{Czy lubisz daną postać?}

Tak Nie

Za co ją lubisz/nie lubisz?

\section{Czy podoba Ci się jej mowa?}

Tak Nie

Jeśli tak, to co jest w niej fajnego?

Jeśli nie, to co Ci się w niej nie podoba?

\section{Czy umiesz mówić tak jak ona?}

Tak Nie

Jeśli tak, to zaprezentuj.

\section{Literatura}

Izdebska Jadwiga, 2001, Rodzina - dziecko - telewizja. Szanse wychowawcze i zagrożenia telewizji, Białystok: Wydawnictwo Trans Humana.

Kita Małgorzata, 1993, Odmiany językowe w telewizyjnych programach dla dzieci i młodzieży, „Z Teorii i Praktyki Dydaktycznej Języka Polskiego”, t. XII, s. 96-109.

Kołodziejczyk Anna, 2003, Dziecięca koncepcja fikcji, czyli co jest „na niby” w telewizji, Kraków: Wydawnictwo Uniwersytetu Jagiellońskiego.

Korzeniowska Monika, 2016, Bohaterowie bajek animowanych $w$ życiu dziecka ( $w$ świetle własnych badań empirycznych), [w:] M. Butkiewicz, A. Gralczyk, K. Marcyński SAC (red.), Dziecko w mediach, Warszawa: Wydawnictwo Dom Wydawniczy Elipsa, s. 73-92. 
Łobos Anna, 2003, Język czasopism i programów telewizyjnych dla dzieci, Katowice: Wydawnictwo Uniwersytetu Śląskiego.

Sak Klaudia, 2016, Wpływ telewizji na rozwój dzieci, [w:] E. Brzyszcz, S. Kozieja (red.), Dziecko i nauczyciel w świecie mediów, Kielce: Wydawnictwo Uniwersytetu Jana Kochanowskiego, s. $179-187$.

Samborska Iwona, 1999, O języku bajek w telewizji, „Wychowanie w Przedszkolu”, nr 10, s. 727-731. Samborska Iwona, 2004, Dziecko i telewizja. Reklamy i bajki telewizyjne a zachowania językowe współczesnego przedszkolaka, Bielsko-Biała: Wydawnictwo ATH.

Wilkoń Aleksander, 2000, Typologia odmian językowych współczesnej polszczyzny, Katowice: Wydawnictwo Uniwersytetu Śląskiego.

\section{Streszczenie}

Artykuł stanowi doniesienie $\mathrm{z}$ badań prowadzonych w jednym z miejskich przedszkoli w Pabianicach, których głównym celem było określenie wpływu zaburzeń mowy wybranych postaci z bajek, filmów bądź kreskówek na rozwój mowy dzieci. Za cele szczegółowe postawiono porównanie liczby oglądanych bohaterów z zaburzeniami mowy, czasu poświęcanego na ich oglądanie oraz naśladownictwa mowy bohaterów przez dzieci z wadami wymowy a dzieci bez wad. Sformułowano także szanse i zagrożenia wynikające z ich oglądania oraz to, jakie jest stanowisko rodziców w kwestii wpływu wymowy postaci z bajek na mowę dzieci. Tego typu obserwacje, prowadzone na gruncie logopedii, jak dotąd nie były prezentowane w literaturze polskiej.

Summary

The article is a report from the studies conducted in one of the Municipal Kindergartens in Pabianice. The main purpose of the studies was to determine the effects of speech disorders in selected characters from fairy tales, films, cartoons and their impact on the development of children speech development. The specific goals are as follows: to compare the number of observed heroes with speech disorders, the time spent by children watching them, mimicking character speech by children with speech disorders and children without defects. The opportunities and threats resulting from their viewing were presented and what the position of parents regarding the influence of the pronunciation of fairy tale characters on children's speech is. This type of observations formed on the ground logopaedics, have not yet been published in the available Polish literature. 